\title{
10. Cahiers du cinéma and Jean-Luc Godard
}

\begin{abstract}
This chapter focuses on the relationship between Cahiers du cinéma in the post-1968 period and the nouvelle vague filmmaker Jean-Luc Godard. The links between the two ran deep: Godard had been a critic for the journal in the 1950s, while in the 196os and 1970s he stood alongside Straub/Huillet as the quintessential representative of political cinema for Cahiers, with the increasingly radical content of his films mirrored by a restless experimentation with film form. Indeed, it was Godard's initial turn to Maoism in 1969 (and his formation of the "Groupe Dziga Vertov" with Jean-Pierre Gorin) that was a major influence on Cahiers' own political trajectory, and one of the landmarks of the journal's long-standing interest in the director was the series of texts on the films of the Groupe Dziga Vertov published in 1972, which are analyzed here.
\end{abstract}

Keywords: Cahiers du cinéma, Jean-Luc Godard, Groupe Dziga Vertov, Marxism-Leninism, political cinema, Tout va bien

\section{Fellow Travelers: Cahiers du cinéma and Godard in the 196os}

Along with Straub/Huillet, Godard forms the other half of what Daney termed le strobgodar, a two-headed monster which, in the critic's view, "is presiding over the end of modern cinema"1 but which also safeguarded the journal's continued interest in the cinema, even at the height of its Maoist period. As Bonitzer has stated, "In all these years, in the most heightened, most dogmatic, closed off militant period, as well as in more open times, the fact that we did not let go of the red thread of Godard's work allowed us to

Fairfax, D., The Red Years of Cahiers du Cinéma (1968-1973). Volume I: Ideology and Politics. Amsterdam: Amsterdam University Press, 2021 DOI 10.5117/9789463728508_CH10 
remain connected to the cinema." The journal's defense of Godard, along with Straub/Huillet, was a tenacious one and was perhaps the key point of distinction between Cahiers and other left-wing cinephilic currents. Daney, for instance, vividly recalls his experience lecturing on the two filmmakers to gauchiste students: "For our first course at Censier, Pascal Bonitzer and myself, mortified at the front of the lecture hall—with radical students itching to start a fight, whose cinematic tastes oscillated between Sam Peckinpah and Francesco Rosi-howled in blanching voices that materialist cinema was Godard and Gorin's Vent d'Est and the Straubs' Nicht versöhnt, and that on this point there was to be no compromising."3 Indeed, Godard was an ever-present point of reference for the journal and has remained so for the Cahiers writers up to the present day. Moreover, his own political evolution was closely aligned with that of the journal, as, like Cahiers, the director became steadily radicalized throughout the 196os, culminating in a turn to Maoism in the early 1970s, and then critically re-evaluated his prior conceptions of political cinema in the latter part of the decade. This parallel development can at least partly be ascribed to the intellectual influence Godard had on the young critics, as the increasingly radical nature of his work prompted them to further push their own theoretical and political viewpoints. As a former writer for Cahiers, Godard maintained close links to the journal, and it was due to the initiative of Narboni in 1968 that his early film criticism was anthologized for the first time. ${ }^{4}$ It was only for a brief period in 1969-1971 that relations between the journal and filmmaker were distant, due primarily to Godard's disdain for his former employer's PCF-aligned "revisionism." Outside of this interlude, Cahiers devoted a large number of articles responding to the release of Godard's films and accorded him interviews on several occasions.

Godard's early films were a touchstone for the cinephilic awakening of many of the younger Cahiers' critics, even before they joined the journal. At the same time, both Comolli and Narboni published reviews of Godard films (Le Petit Soldat and Le Mépris respectively) shortly after joining the journal. This engagement with the filmmaker continued later in the $1960 \mathrm{os}$ and initially emphasized the groundbreaking formal techniques of Godard's work. In 1965, Comolli's review of Alphaville insisted on its political relevance,

2 Bonitzer, “Nos années non légendaires," p. 152.

3 Daney, Persévérance, p. 92 [p. 76].

4 See Jean Narboni (ed.), Godard par Godard (Paris: Pierre Belfond, 1968). This edition appeared in English in 1972 (translated and edited by Tom Milne), and an expanded version edited by Bergala was published by Cahiers in 1984, with a second volume following in 1998. 
arguing that "the immediate future spoken of by the film is indeed our contemporary era: here, we are the voyeurs of ourselves." Godard's filmmaking was "creation against the grain," and his films were "never truly finished, the puzzle is never complete; new pieces can always be integrated into it." In January 1967, Narboni focused on the formal structure of Deux ou trois choses que je sais d'elle, seeing its collage-like structure as an "atomic" movement in which "the random jumps of the electrons from one orbit to another integrate themselves into a vaster gravitation." ${ }^{6}$ The journal's response later that year to La Chinoise - whose depiction of a Parisian cell of Maoist students uncannily presages the later political development of Cahiers - combined these two perspectives. Bontemps labeled the film a "political act" due to its "radical interrogation of the cinema and profound engagement in this art," while Comolli perceived it to be "all told, the most plastic and the most political film" in Godard's œuvre. ${ }^{7}$ Comolli's review foreshadowed the semiological mode of film analysis that would impregnate much of Cahiers' later writings by arguing that "what every film timidly suggests to its spectator, that its images should be read, La Chinoise demands more expressly: the image should be read, and nothing in it should not be read, since anything that cannot be read in it is not there." ${ }^{3}$

In the same issue (October 1967), Cahiers published a long interview with Godard which served as a clarion call for the intensification of the journal's political radicalism - even the title, "Lutter sur deux fronts," is indicative of this perspective. Godard had already granted two interviews to Cahiers (in 1962 and 1965), both of which discussed the relationship of cinema to film criticism. In the first, he famously declared: "Today I still consider myself a critic, and, in a sense, I am one more than ever. Instead of writing criticism, I make films, and try to introduce a critical dimension to them."9 Insisting that if the cinema disappeared, he would continue to make film

5 Jean-Louis Comolli, “À rebours? (Alphaville)," Cahiers du cinéma no. 168 (July 1965), pp. 86-87, here p. 87 .

6 Jean Narboni, "Notes sur 2 ou 3 choses que je sais d'elle," Cahiers du cinéma no. 186 (January 1967), pp. 32-33, here p. 33. Translated as "Notes on Two or Three Things...," Cahiers du Cinéma in English no. 10 (May 1967), p. 31.

7 Jacques Bontemps, "Une libre variation imaginative de certains faits (La Chinoise)," Cahiers du cinéma no. 194 (October 1967), pp. 30-34, here p. 34; and Jean-Louis Comolli, "Le point sur l'image (La Chinoise)," Cahiers du cinéma no. 194 (October 1967), pp. 29-30, here p. 29.

8 Ibid.

9 Jean-Luc Godard, interviewed by Jean Collet, Michel Delahaye, Jean-André Fieschi, André S. Labarthe and Bertrand Tavernier, "Jean-Luc Godard," Cahiers du cinéma no. 138 (December 1962), pp. 21-39, here p. 21. Translated as "Interview with Jean-Luc Godard," in idem., Godard on Godard, pp. 171-196, here p. 171. Godard's last critical piece for Cahiers was published a little more than 
with "a pencil and paper," Godard nonetheless lamented the loss, by 1962, of the polemical spirit of the 1950s, which would be revived a fortiori in the post-1968 years: "The thing that made Cahiers was its position in the front line of battle. [...] The Cahiers critics were commandos. Today, they are an army at peace, going out on maneuvers from time to time." ${ }^{10}$ By 1965 , he claimed that film criticism had attained its "age of reason" and was "almost at the point reached by art and music critics: giving information is not enough, there is nothing to explain, less need to defend and attack." ${ }^{\prime 11}$ At the same time, Godard argued that the literary style of the earlier period of criticism had to make way for a "pedagogical criticism" that would educate the reader on the work of figures such as Straub, Bertolucci and Skolimowski.

The ${ }^{196} 67$ interview "Lutter sur deux fronts," ostensibly focused on $L a$ Chinoise, in fact broached a wide range of topics relating to the nexus between cinema and politics, attesting to the more radical outlook shared by Godard and Cahiers at this time. The fruit of Godard's contact with members of the UJCM-L and the radical students at Nanterre University, La Chinoise nonetheless, as the director admitted, intensely displeased those Maoist students who served as its inspiration: "I've made a movie I call La Chinoise, in which I adopt, against the point of view of the French Communist Party, the point of view of the writings of Mao Zedong or the Cahiers marxistes-léninistes. I repeat, it is film that's imposed the direction I take, which explains why the Cahiers marxistes-léninistes can accuse it of being 'leftist' and why L'Humanité nouvelle can even attack it for being a 'fascist provocation."'12 But Godard felt that this was primarily due to the fact that he "didn't make it clear enough that the characters aren't members of a real Marxist-Leninist cell. They ought to have been Red Guards. I'd have avoided certain ambiguities. The real activists [...] wouldn't have been as annoyed by it as they were." ${ }^{13}$ The conversation with Cahiers subsequently moved into more theoretical terrain.

two years earlier, in April 196o. See Jean-Luc Godard, "Frère Jacques," Cahiers du cinéma no. 106 (April 1960), p. 4. Translated as "Frère Jacques," in idem., Godard on Godard, pp. 163-164.

10 Godard, in Collet et al., "Jean-Luc Godard," pp. 20, 38 [pp. 171, 195].

11 Jean-Luc Godard, interviewed by Jean-Louis Comolli, Michel Delahaye, Jean-André Fieschi and Gérard Guégan, "Parlons de Pierrot: nouvel entretien avec Jean-Luc Godard," Cahiers du cinéma no. 171 (October 1965), pp. 18-34, here p. 33. Translated as "Let's Talk about Pierrot," in idem., Godard on Godard, pp. 215-234, here pp. 229-230.

12 Jean-Luc Godard, interviewed by Jacques Bontemps, Jean-Louis Comolli, Michel Delahaye, Jean Narboni, "Lutter sur deux fronts: conversation avec Jean-Luc Godard," Cahiers du cinéma no. 194 (October 1967), pp. 12-26, 66-7o, here p. 16. Translated as "Struggle on Two Fronts: A Conversation with Jean-Luc Godard," trans. D.C.D., Film Quarterly, vol. 22 no. 2 (Winter 1968-1969), pp. 20-35, here p. 23 .

13 Ibid., p. 15 [p. 21]. 
Here, after critiquing the film semiology of Metz and Pasolini, Godard in effect anticipates the line of thought developed by Comolli in "Technique et idéologie": having recently purchased an editing table, the filmmaker notes that the very design of the apparatus enforces a Hollywood mode of continuity editing that inhibits any radical experimentation with montage in the vein of Eisenstein and Resnais, and he concludes from his experience that "it comes down to a simple economic gimmick that all by itself bears out a whole ideology. [...] If you're trying to make revolutionary movies on a reactionary editing table, you're going to run into trouble." He even, albeit semi-seriously, hints at the idea of writing a text for Cahiers:

The only thing I'd want to write for Cahiers now - it would take time to do it; I'm always running into something else to say on the subject-would be something about the ways to get film off to a complete new start. I'd discuss it in terms of the problems a young African would have to face. I'd tell him, "All right, your nation has just won its freedom. Now that you're free to have a film of your own, you and your comrades have been asked to get it started." ${ }^{\prime 14}$

This passage not only portends Godard's participation in the founding of Mozambican television after the country's independence in the late 1970s, it also heralds the prolonged concern for Third World, anti-imperialist cinema that will appear on the pages of Cahiers in the ensuing decade.

\section{8-1972: Alienation and Reconciliation}

If La Chinoise prophesied the rise of the Maoist movement of the early 1970s, which would engulf both Godard and Cahiers, the filmmaker's next work, Week-End, was the culmination of a cinematic crisis that had besieged Godard since at least his 1965 statement "Pierrot mon ami" (published in Cahiers), where he hauntingly called out: "the only great problem with cinema seems to me more and more with each film, to be when and why to start a shot and when and why to end it?"'5 Week-End, therefore, not only consisted of a rebarbative attack on contemporary bourgeois civilization and a definitive rupture with the commercial film industry (signaled by

14 Ibid., p. 25 [p. 29].

15 Jean-Luc Godard, "Pierrot mon ami," Cahiers du cinéma no. 171 (October 1965), pp. 17-18, here p. 17. Translated as "Pierrot My Friend," in idem., Godard on Godard, pp. 213-215, here p. 214. 
the "Fin de cinéma" title-card in the film's closing credits), it also consisted of a zero-point of cinematic montage, a tabula rasa on the basis of which Godard, in his ensuing Marxist-Leninist period, could experiment with new methods of "building" film images. ${ }^{16}$ This is recognized by Aumont in his review of the film, as the critic speaks of Week-End as a collection of "floating splinters, whose assemblage in a film evokes a submersed continent from which emerge only a few islands" whilst recognizing that "all these disjointed fragments are nonetheless crisscrossed underground by the same dialectical movement, one between softness and violence, tenderness and cruelty." The film's status as a "site for the encounter of two antagonistic formal categories, whose jolting coexistence defines the film's dynamic" - namely, the "cry" and the "murmur" - even leads Aumont to question the very status of film criticism, and he thus concludes his article by citing Blanchot's claim that "the critic is by nature on the side of silence." 7

Oudart conveyed similar ideas in his response to Godard's One Plus One, albeit expressed in that critic's favored semio-psychoanalytic terminology: while conceding that the problem posed by the film was "always the same: the relationship between political discourse and the political gesture, between erotic discourse and the erotic act, between creative practice and the work," he argued that One Plus One's "revolutionary action" consisted of "perceiving the poverty of the signified while discovering the play of the signifier, in the gaps of which can be traced out the promise of all possible meanings. ${ }^{18}$ Three months later, in September 1969, Aumont's report on the Berlin film festival was effusive in its enthusiasm for Le Gai Savoir (which screened for the first time after having been censored by the ORTF ${ }^{19}$ ), calling it the "first entirely theoretical film in the history of the cinema" while acknowledging that its conceptual density required "a more elaborate approach" than that allowed for by "the rapidity of a festival notice."20

A more detailed discussion of Godard's films had to wait for another three years-a period in which the director, either alone or as part of the "Groupe Dziga Vertov," completed no less than seven films and worked

16 For more on the role of montage in the work of Jean-Luc Godard, see Daniel Fairfax, "The Dialectics of Montage in Jean-Luc Godard (1965-1998)," MPhil thesis, University of Sydney, 2010. 17 Jacques Aumont, "Létang moderne (Week-End)," Cahiers du cinéma no. 199 (March 1968), pp. 59-6o.

18 Jean-Pierre Oudart, "Dans le texte (One Plus One)," Cahiers du cinéma no. 213 (June 1969), pp. 59-6o.

19 In a snub to the French censors, Cahiers published extracts from the soundtrack in issue no. 200-201, pp. 53-55.

20 Jacques Aumont, "Berlin 69," Cahiers du cinéma no. 215 (September 1969), pp. 41-46, here p. 46 
on several other unfinished projects. While the work of Straub, Jancsó, Buñuel, Kramer, Oshima and Rocha was discussed at length during this time, Godard's output was rarely mentioned in anything more than a cursory fashion. On the surface, it seems anomalous that Cahiers - at the height of its Marxist period, in which its stated mission of defending films that yielded a "critical de-construction of the system of representation" - should be so taciturn about a filmmaker whose work, more than that of any of his contemporaries, embodied precisely this goal. In fact, this situation was determined by Godard's political opposition to Cahiers' strategy of aligning itself with the PCF. By late 1968, the filmmaker identified closely with the Maoist movement in France, and his chosen collaborators in the years 1969-1972, including Jean-Henri Roger and Jean-Pierre Gorin, were drawn from the ranks of the pro-Chinese student left. In October 1968, shortly after the publication of Godard par Godard under Narboni's auspices, Godard took the step of removing his name from Cahiers' comitéde rédaction (although his active participation in the committee was very limited in the first place). In a further embarrassment for the Cahiers editors, the inaugural issue of Cinéthique featured an interview with Godard in which the filmmaker vocally censured Cahiers for being subservient to its owner Filipacchi, presciently stating: “The problem for Cahiers du cinéma: nothing's changed. They are completely imprisoned — even if they knew what to write-unless they intend to stop the journal and write what they need to write. But then Filipacchi will stop them, because Filipacchi cannot publish the Cahiers marxistes-léninistes. ${ }^{21}$ Cinéthique continued to be the recipient of Godard's favor, screening his films at public events and publishing a statement on British Sounds at his behest. ${ }^{22}$ Elsewhere, the filmmaker criticized Comolli and Labarthe's documentary on the 1968 legislative elections, Les deux Marseillaises, for its ostensibly even-handed approach towards the major political parties, claiming that "this type of cinema represents the position of Le Monde, the position we call objective, an 'objectivity' that is the myth of liberal countries like England. Objectivity consists of showing both Jews and Hitler, for example: ten minutes of Hitler and then ten minutes of Jews. It does indeed seem objective, because they both have ten minutes, but it is meaningless." ${ }^{23} \mathrm{~A}$ further slight to Cahiers, which was in the midst of its

21 Godard, "Un cinéaste comme les autres," p. 12.

22 Jean-Luc Godard, "Premiers ‘sons anglais," Cinéthique no. 5 (September-October 1969), p. 14.

23 Jean-Luc Godard, interviewed by Alain Jouffroy, "Entretien," Le Fait public no. 2 (January 1969), repr. in Jean Collet (ed.), Jean-Luc Godard, $4^{\text {th }}$ ed. (Paris: Éditions Seghers, 1974), pp. 145-157, here p. 149. 
mammoth Eisenstein translation project, can even be perceived in the name of the "Groupe Dziga Vertov" (GDV). On the soundtrack to Vent d'Est and in numerous interviews given at the time, the work of the "revolutionary" Vertov was directly opposed to that of the "revisionist" Eisenstein. ${ }^{24}$

Cahiers nonetheless remained diplomatic when it came to Godard's work: prompted by queries made by numerous readers as to their relationship with the filmmaker, Comolli (in the same issue as Aumont's discussion of Le Gai Savoir) noted that the "beginning of a response" was already underway. It would have taken the form, he relates, of:

a long interview (or rather discussion) with Godard, on the subject of his departure from Cahiers, his reasons for doing so, and the declarations that he has made in various places about Cahiers and politics. This discussion (in which Delahaye, Narboni and myself participated) was recorded, transcribed and given back to Godard so that he could re-read it and correct his interventions (as we usually do). After long delays, Godard ended up telling us that he preferred for the interview not to be published. More's the pity. ${ }^{25}$

Comolli promised "something else, which is in the pipeline and which should appear in a coming issue," and advised readers to watch Un film comme les autres and British Sounds in the meantime. Advertisements in subsequent issues would list a special issue on Godard among the texts that "Cahiers will publish," but political considerations during the journal's rapprochement with the PCF prevented this dossier from being realized. The "Journal de la rédaction" for February 26, 1971 noted the need to include an "introductory text in order to clarify that we are not in agreement with the slandering of the party," and the dossier came to be jokingly known within the Cahiers team as "Luttes en litanie." ${ }^{26}$ Thus, despite his prolific output, throughout 1970 and much of 1971 public discussion of Godard's latest work was largely

24 See, for instance, Jean-Luc Godard and Jean-Pierre Gorin, interviewed by Marcel Martin, “Le Groupe ‘Dziga Vertov,” Cinéma 70 no. 151 (December 1970), repr. in Jean-Luc Godard, Godard par Godard vol. I: 1950-1984, ed. Alain Bergala (Paris: Cahiers du cinéma, 1998), pp. 342-350, p. 343.The distinction made between Vertov and Eisenstein is defended chiefly through their contrasting attitudes towards "bourgeois" fiction. On a strictly political level, there was no clear distinction between the two: both were enthusiastic supporters of the Bolsheviks in the early years of Soviet rule, and both would fall foul of the Stalinist censorship regime in the 1930 and 1940 s.

25 Jean-Louis Comolli, "Le cahier des lecteurs," Cahiers du cinéma no. 215 (September 1969), pp. 4-9, here p. 9 .

26 See de Baecque, Histoire d'une revue vol. II, p. 248. 
avoided by the journal, whose editors were hesitant about entering into the potential political minefield posed by the contradiction between Godard's Maoism and their own proximity to the PCF.

This impasse was broken in May 1971 by Bonitzer, who concluded his article "Réalité de la dénotation" with the claim that Groupe Dziga Vertov films such as Vent d'Est and Pravda provided the possibility for "overthrowing" the ideology overdetermining the preeminence of figuration in the cinema by offering a "political reading" that was "diagonal to the surface of representation" and was capable of opening the film up to "another scene" - that of political economy. ${ }^{27}$ The same issue published an interview the editors gave to Politique-Hebdo in which they argued that the recent work of the Groupe Dziga Vertov, and above all Luttes en Italie, represents "one of the rare attempts - referring explicitly to historical and dialectical materialism - to strive, with difficulty, to develop its specific (cinematic) practice on this basis. ${ }^{28}$ In a subtle shift away from its previous focus on Eisenstein, Cahiers also began to place more emphasis on publishing the theoretical writings of Dziga Vertov. Taken together, these gestures represented a significant attempt to orient the journal towards Godard's latest work. Its allegiance to the filmmaker was sealed in the October 1971 issue, when Cahiers' conversion to Maoism removed the final barrier to co-operation with the GDV. The journal heralded the shift by emblazoning its front cover with a still from Vladimir et Rosa, the most recent film made by Godard/Gorin at the time.

\section{On the Films of the Groupe Dziga Vertov}

In mid-1972, the long-promised dossier on the films of Godard's Marxist-Leninist period was finally published. Both the May-June and July-August 1972 issues engaged deeply with his work, treating, in parallel articles, the films made under the rubric of the "Groupe Dziga Vertov" (British Sounds, Pravda, Vent d'Est, Luttes en Italie and Vladimir et Rosa) and Godard/Gorin's higherprofile release Tout va bien. This endeavor was signed by the "Groupe Lou Sin d'intervention idéologique," whose very name (drawn from the early twentieth-century Chinese poet Lu Xun, a close confidante of Mao's in the

27 Pascal Bonitzer, “Réalité’ de la dénotation,” Cahiers du cinéma no. 229 (May 1971), pp. 39-41, here p. 41. Translated as “'Reality' of Denotation,” trans. Lindley Hanlon, in Browne (ed.), Cahiers du Cinéma vol. III, pp. 248-253. This article will be further discussed in Chapter 25 .

28 “Réponses à Politique Hebdo," Cahiers du cinéma no. 229 (May 1971), pp. 61-64, here p. 62. 
pre-revolutionary era) was obviously modeled on the moniker adopted by Godard/Gorin. The division of their corpus from the years 1969-1972 into two separate articles reflected Cahiers' recognition of the fundamental difference between Tout va bien and the preceding films: whereas the GDV films were seen as works of Marxist-Leninist theoretical practice, Tout va bien, with its larger budget, a more recognizable narrative and big-name stars (Yves Montand and Jane Fonda) was understood, in a Gramscian vein, as a "national-democratic" art work involving a conscious use of Brechtian dramatic devices and a strategy aimed at appealing to a wide audience. Indeed, the extent to which Tout va bien can even be included in JeanLuc Godard's filmography is open to debate: having been incapacitated in a motorcycle accident in 1971, the filmmaker later estimated his own contribution to the film to be roughly $5-6 \%$, with Gorin largely responsible for writing and directing duties. ${ }^{29}$ Although Tout va bien pastiches earlier Godard films, the comparatively taut storyline and the tendentiousness of certain scenes is an anomalous departure from the rest of Godard's œuvre, and Cahiers is therefore justified in treating the GDV films separately to Tout va bien. Moreover, despite occupying similar political ground to Godard/ Gorin, differences in line remained between the journal and the filmmakers. Whereas Cahiers remained skeptical of the existing Maoist groupuscules, Godard and Gorin gravitated towards the "Mao-Spontex" current: close relations with Vive la révolution! (Vladimir et Rosa), and the ex-Gauche prolétarienne (Tout va bien) are discernible in their films, and Godard even wrote articles for the latter organization's newspaper J'accuse..$^{0}$ The Cahiers texts on Godard/Gorin's films also served a secondary purpose, to differentiate Cahiers' perspective on this attempt at Marxist filmmaking from the analysis already carried out by their peers at Cinéthique, who had written at length on the GDV's work both in their own journal and in other outlets such as the radical art journal $\mathrm{VH}_{1010^{3}}$

The Groupe Lou Sin's two-part article “Le 'Groupe Dziga-Vertov': Sur les films du 'groupe"” offered a critical analysis of this corpus, charting Godard's passage from an "anarchistic" ideologico-political orientation in La Chinoise,

29 See Jean-Luc Godard, "Warum ich hier spreche...," translated into German by Gerhard Theuring, Filmkritik vol. 19 no. 9 (September 1975), pp. 420-429, here p. 421.

30 These articles were later reprinted in Nicole Brenez and Michael Witt (eds.), Jean-Luc Godard: Documents, pp. 174-177. The supermarket scene in Tout va bien was inspired by similar actions carried out by Gauche prolétarienne militants in the early 1970s.

$31 \quad$ See Gérard Leblanc, "Quelle avant-garde?," Cinéthique no. 7-8 (c. late 1970), pp. 72-92; Gérard Leblanc, "Sur trois films du Groupe Dziga Vertov," VH 101 no. 6 (1972), pp. 21-36; and Gérard Leblanc, "Lutte idéologique et Luttes en Italie," VH 10 no. 9 (Autumn 1972), pp. 73-99. 
Week-End and One Plus One to a "practice more rigorously determined by politics" in subsequent films. In the Groupe Lou Sin's view, the initial films of this post-1968 period nonetheless still bore traces of Godard's auteurist past. Un film comme les autres is criticized for its "'musical' conception of montage," which merely mimes the "anarchism and spontaneism of the movement," while the "empirical filming" of British Sounds and the unfinished One A.M. are also mostly disdained. These films do represent the beginning of the "principle of an ideological intervention of the voice-over on the image-track," but it is Pravda that is "the first systematic attempt to struggle on two heterogeneous fronts, which all the other films of the group will inscribe: the political struggle (against the bourgeoisie and revisionism) and the struggle on the front of the 'philosophy of images and sounds." Pravda, Vent d'Est and Luttes en Italie thus constitute a veritable MarxistLeninist triptych: all three films adopt a tripartite structure that strives to mime the "practice-theory-transformed practice" dialectic posed by Mao. ${ }^{32}$ To a certain extent, however, this theoretical approach is symptomatic of the absence of any concrete political effect that the GDV films might have: unlike the Soviet cinema of the 1920s, France in the 1970s lacked a mass revolutionary party towards which Marxist filmmakers could orient their work. While Cahiers argue that the fact that the films forcefully pose the question "For whom? Against whom?" points to an overturning of "the concept of art that has reigned in Western metaphysics," they acknowledge that because these films operate outside of any "social or libidinal demand" (there is little public desire for such films, even amongst left-wing militants), they are instead more profitably situated within the sphere of theoretical research: "they explore a fallow ideological terrain, the relationship of representation to its political 'outside,' the inscription of this outside in the scene of representation, the material scene of images and sounds." 33

Pravda, which treats the political situation of Czechoslovakia after the Soviet invasion, represents "the first time that a film has posed the necessity of philosophical work for transforming the practice of images and sounds" due to the fact that its own production of images is subject to critique on the

32 The Cahiers dossier included transcriptions of the bandes-sonores of all three films, documents that now constitute valuable pedagogical aids to a deeper understanding of these complex cinematic objects. See "Bande paroles de Luttes en Italie," Cahiers du cinéma no. 238-239 (MayJune 1972), pp. 40-57; "Bande paroles de Pravda," Cahiers du cinéma no. 240 (July-August 1972), pp. 19-30; and "Bande paroles de Vent d'est," Cahiers du cinéma no. 240 (July-August 1972), pp. 31-50. 33 The quotes from this paragraph are from the Groupe Lou Sin d'intervention idéologique, "Le 'Groupe Dziga-Vertov': Sur les films du 'groupe' [Part 1]," Cahiers du cinéma no. 238-239 (May-June 1972), pp. 34-39, here pp. 34-35. 
soundtrack. And yet it is deemed to be a "mechanistic, dogmatic film" whose "broad, reciprocally overdetermined political and philosophical contours are erroneous." The chief source of Pravda's theoretical deficiency derives from the "dogmatic error" of transposing Mao's distinction between "perceptual knowledge" and "conceptual knowledge" into a "metaphysics of the true and the false," one that derives from the film's chosen method of placing "just sounds" (Marxist texts) over "false images" (the "empirical" footage of Czechoslovakia shown in the film). The provenance of this philosophical solecism is understood to reside in "Althusser's thesis of the ideology/science cleavage, a thesis, revisionist in nature and drawn from bourgeois origins (Bachelard), that tends to occlude the class struggle within ideology," and it is accompanied by the film's chief political error, which consists of a "unilateral condemnation of the petty-bourgeois character of the revolt of the Czech people against Soviet social-imperialism" and an insufficient analysis of the nature of revisionism. ${ }^{34}$

Derived from a project to film a "Marxist Western" in Italy with the participation of Daniel Cohn-Bendit and Gian-Maria Volonte, Vent d'est is a critique of the errors of Pravda. Its key slogan- "Not a just image, just an image"35_is an unmistakable retort to the earlier film's sterile dichotomy between "just sounds" and "false images." For Cahiers, the fact that the "weight of 'objective reality' of the referent" is no longer operative (the film is based on a fictional premise rather than documentary footage) means that the GDV is free to "interrogate the role of images and sounds in the material production of the ideological effects of all those films collected under the rubric of the Western." The result of a "takeover" at the editing stage by the crew's "Marxist-Leninist minority" (Gorin, essentially), Vent d'est's ambitious nature stems from its goal of producing "an overview of both the history of the cinema and the political history in which it is inscribed." It is marred, however, by "ideological errors of an ultra-left variety" - exemplified, in particular, by the penultimate sequence justifying acts of terrorist violence in the name of a "civil war between capital and labor."36

While the "undeniably productive effects of irrationality" in Vent d'est led the Groupe Lou Sin to dub it the "richest and most accomplished" of

34 Ibid., pp. 36-37. The term "social-imperialism" referred to the Maoist notion that the USSR, in spite of its socialist economy, had become an imperialist power akin to those of the capitalist West.

35 Although this phrase is primarily associated with Godard, it was actually devised by Gorin. Godard admitted to this in a radio interview in 1989. See Jean-Luc Godard, interviewed by Noël Simsolo, À voix nues, France Culture, November 21, 1989.

36 Groupe Lou Sin, “Le 'Groupe Dziga-Vertov' [Part 1]," pp. 37-38. 
Godard-Gorin's films, Luttes en Italie was seen as the theoretical culmination of the Marxist-Leninist triptych. An overt attempt to "adapt" Althusser's theoretical text "Idéologie et les appareils idéologiques d'état" to the screen, the film is the most structured, systematic attempt made by the GDV to produce a "political/philosophical critique of the 'innocence of vision,' the myths of obvious truth [évidence] and immediate knowledge [connaissance], of direct access to the real, which are ideologically defined by empiricism and spontaneism (in the broader and narrower sense of this word)." Its mission of grappling with the ideological mechanisms that overdetermine "the sacrosanctity of film technique" is, it goes without saying, one that is shared by Cahiers. But it also represented the end point of this project: after Luttes en Italie, the GDV attempted to "connect with the masses in struggle" by working under the political direction of the Palestinian liberation movement in the unfinished Jusqu'à la victoire and realized a burlesque political sature in Vladimir et Rosa before the failed effort at a commercially oriented film with revolutionary politics in Tout va bien. The impasse reached by the GDV led the Cahiers writers to ponder whether it is even possible for audiences to receive in anything other than a hostile manner a political cinema divorced from the prevailing critical realism of bourgeois ideology: "If realism is suppressed," they speculate, then "(active, frank and trenchant) critique becomes intolerable." 37

This more general question is addressed in the second installment of the Groupe Lou Sin's text. The difficulty so often attested in comprehending the GDV's films is not, they claim, incidental. Nor does it arise from any ambiguity in the films, which are in fact stridently unambivalent and openly avow their own mechanisms of signification. Rather, it derives from the "apparent complexity of a model overriding the apparent simplicity of its referent." This gives rise to a double reproach: whereas the signified in the GDV films is frequently derided for being "too simplistic, rough, insultingly flat," their construction (the signifier) is equally faulted for being "too difficult, hermetic and elitist because complex. ${ }^{8} 8$ The injunction frequently issued by the GDV - to make films politically, rather than political films - thus results in a radical, conscious interrogation of the relationship between the filmic image and its referent. As the Groupe Lou Sin puts it, the question that the GDV films pose to the viewer is, in essence: "Is presentification equivalent to an assertion? Is a shot of a revolver (to use Christian Metz's famous example) 'groupe' (2)," Cahiers du cinéma no. 240 (July-August 1972), pp. 4-9, here p. 6. 
equivalent to the phrase 'Here is a revolver'?"39 Whereas conventional film practice answers resoundingly in the affirmative, even when the subjectmatter is overtly political in nature, the GDV's chief theoretical advance was their recognition of the constitutive heterogeneity of their films-in particular, the disjunction between image and soundtrack. Although initially understood dogmatically (i.e. Pravda's opposition between false images and just sounds), this factor is productively developed to the point that the tacit goal of the GDV's work is the production of a "just discourse on just some images [juste des images]."40

These two terms are, however, interrogated by Cahiers: a sound/text can never simply be the illustration of an image or vice versa. This would suppose the possibility of a direct translation between the two media, an equivalence between a shot of a revolver and the phrase "Here is a revolver." Rather, "what takes place is more complex and more perverse than what a simplistic theory of communication is able to grasp." Whenever a sound (discourse) is used to designate an image, a "supplementary sheath" is intercalated between "the utopian immediacy of the real and its transcription," which ends up avowing the fact that an image is not merely visual in nature but is the "exorbitant place-holder of the real" of which "this limitation of its power deprives us." The mere avowal of the notion that an image is "just an image" on the soundtrack, however, is insufficient for materialist film practice. So a further step is taken by the GDV, whose films "keep the spectator at a distance by exercising, in their stead, a knowledge of that which the images remain silent about" and not a knowledge in the monolithic form of "that's how it is." In Luttes en Italie, this passage is metaphorically relayed by the replacement of the black images of the first part of the film (whose presence is questioned by the voice-over in the second part) by "images of relations of production"-specifically, a proletarian operating a machine in a factory. But it is only by means of the voice-over that the viewer is to know that this image is to be read as an "image of relations of production." As Cahiers point out, it would in fact be more apt to denote such an image as one of "productive forces" rather than "relations of production" (two distinctly different concepts in Marxist political economy). More importantly, merely showing such an image gives little theoretical insight into the social functioning of the referent. Luttes en Italie thus remains on the level of a simulacrum of the "just" position of the spectator and is incapable of ascending to the level of Marxist theory as its authors intended. In spite of this limitation, Cahiers 
place great value on the works of the GDV: "It is because these films simulate the production of the knowledge that they exercise with the aid of the concepts of Marxism-Leninism that their object (their referent) is produced instead of being given, and problematic instead of being ambiguous. ${ }^{241}$

\section{Coup pour coup vs Tout va bien: Pathways to a Brechtian cinema}

Cahiers also devoted a lengthy and influential article to a comparison of Tout va bien and Coup pour coup by Marin Karmitz. ${ }^{42}$ The need to contrast the pair of films was self-evident. Coup pour coup and Tout va bien were released within two months of each other (February and April 1972 respectively), and they treat similar subject matter. Inspired by real-life "sequestrations" led by the Gauche prolétarienne, they both depict factory workers taking their boss hostage. Moreover, both films were directed by self-identified Maoists, and they provoked a significant amount of discussion in the French press, a critical corpus that Baudry symptomatically analyzed for Cahiers. ${ }^{43}$ The fact that Godard/Gorin's film was released soon after Karmitz's led to accusations of plagiarism, to which Gorin responded by saying "The phenomena unleashed by the class struggle are nobody's private property. A discussion will inevitably result, which will be extremely beneficial. People can see two types of cinema that amount to two different political positions with respect to the present context." ${ }^{44} \mathrm{He}$ went on to critique Karmitz, arguing that "Coup pour coup is not a contemporary film for us. [...] It's The Salt of the Earth in 1972, and it is in this sense that we are led to attack it.".45

Cahiers followed the signal to attack Karmitz's film. Central to the distinction the journal made between the two films was the question of performance, and, with it, film aesthetics more broadly. To play the role

41 The quotes from this paragrpah are all from ibid., p. 9.

42 Despite not appearing in English translation, this article was one of the most influential Cahiers texts for "political modernist" film theory in 1970s Anglo-American academia. See, for instance, Julia Lesage, "Visual Distancing in Godard," Wide Angle vol. 1 no. 3 (March 1976), pp. 4-13; and Kristin Thompson, "Sawing through the Bough: Tout va bien as a Brechtian film," Wide Angle vol. 1 no. 3 (March 1976), pp. 38-51.

43 Pierre Baudry, "La critique et Tout va bien," Cahiers du cinéma no. 240 (July-August 1972), pp. 10-18.

44 Jean-Luc Godard and Jean-Pierre Gorin, interviewed by Marlène Belilos, Michel Boujut, Jean-Claude Deschamps and Pierre-Henri Zoller, "Pourquoi Tout va bien?: Entretien avec Jean-Luc Godard and Jean-Pierre Gorin," Politique-Hebdo no. 26, April 27 1972. Repr. in Godard, Godard par Godard vol. I, pp. 367-375, here p. 370.

45 Ibid., p. 371. 
of the striking factory workers, Karmitz utilized non-professional actors from working-class backgrounds, prompting a naturalistic acting style with its roots in the "kitchen-sink" realism of British filmmakers such as Tony Richardson and Karel Reisz, an aesthetic further accentuated by the use of on-location shooting and handheld camerawork. Godard/Gorin, by contrast, not only used stars as the leads (Yves Montand and Jane Fonda) but gave the proletarian roles to unemployed actors ${ }^{46}$ and adopted an aesthetic method borrowed liberally from Brecht's practice of the Verfremdungseffekt. Gorin defended this approach as an "attempt at producing materialist fictions," but he also cautioned against an overly schematic application of Brechtian theatrical techniques: "We cannot avoid starting over from a certain number of things Brecht highlighted. This said, we are doing something else entirely, we are making cinema. [...] In any case, the conception that Brecht had of ideology is historically dated." ${ }^{\text {an }}$

The reference to Brecht was indisputably of major importance for $\mathrm{Ca}$ hiers, but the journal's debt to the dramatist should not be overstated. ${ }^{8}$ In November 1970, Narboni asserted, on the occasion of the publication of a collection of Brecht's film-related texts titled Sur le cinéma, that "We will return more broadly to these fundamental texts, whose reinscription and reactivation in the contemporary political and theoretical context must be thought through." ${ }^{49}$ For the most part, however, Brecht's writings were less prominent as an influence than were the theories of Lacan, Althusser and Derrida in the years 1969-1971. 1972, by contrast, saw a flowering of interest in Brecht on the part of Cahiers, as the political efficacy of films gained in importance for the journal. In short, distanciation took the place of deconstruction. In addition to its pertinence to the GDV, Brecht's work was also discussed in relation to René Allio's Les Camisards, and Cahiers reprinted a French translation of his seminal article "Anmerkungen zur Oper Aufstieg und Fall der Stadt Mahagonny" as an appendix to the Groupe Lou Sin's discussion of Coup pour coup and Toutva bien..$^{50}$ Seen as the "ideological

46 In an interview with Le Nouvel Observateur, Godard complained that working-class non-actors had a tendency to "spontaneously" act like Jean Gabin. Cited in Groupe Lou Sin d'intervention idéologique, "Deux Films: Coup pour coup et Tout va bien," Cahiers du cinéma no. 238-239 (MayJune 1972), pp. 5-24, here p. 18.

47 Ibid., p. 373 .

48 This tendency is most flagrant in Lellis' Bertolt Brecht, Cahiers du cinéma and Contemporary Film Theory.

49 Jean Narboni, "Brecht et le cinéma," Cahiers du cinéma no. 225 (November-December 1970), p. 56 .

50 See Jacques Aumont, "Comment on écrit l'histoire," Cahiers du cinéma no. 238-239 (MayJune 1972), pp. 64-70; François Regnault, "Les Camisards et le film d'histoire," Cahiers du cinéma 
'key"' to Godard/Gorin's film, the Mahagonny text differentiates between the dramatic ("culinary") theater and Brecht's own epic ("didactic") approach to mise en scène, which Cahiers understood as mirroring the distinction between the "immutability of being" in idealist metaphysics and the notions of "change, rupture, the becoming of contradictions" inherent to dialectical materialism. The GDV was therefore commended for reviving the relevance of Brecht's theories in the present context, which "today have a decisive importance, ideologically and politically, in the field of cinema." ${ }^{11}$

Cahiers held the reverse attitude towards Coup pour coup: given its long-held antipathy towards cinematic naturalism and the hostility the journal had already shown to Camarades, a negative reaction to Karmitz's new film was to be expected; all the same, the immoderate harshness with which the Groupe Lou Sin denounced Coup pour coup is striking. The film had already been the subject of polemic among Maoist film critics on the pages of Écran 72: for Guy Hennebelle (who held a more utilitarian position on political cinema and detested the formal experimentation of Godard and Straub), Karmitz was "one of the most important French filmmakers of the day," and his work was "remarkable in its power and accuracy." ${ }^{2} \mathrm{By}$ contrast, Cinéthique's Gérard Leblanc condemned the film's spontaneism and opportunism (originating in the "erroneous line" of La Cause du peuple) and judged it to be a "resolutely passive, tail-endist" reflection of the class struggle in France. Cahiers, at this stage rather close to Cinéthique's political outlook (both journals adhered to Maoism but remained distant from the Mao-Spontex tendency), sided with Leblanc against Hennebelle but pushed his critique of Karmitz further. By remaining at the level of "bourgeois reportage," Coup pour coup is not only impregnated with a "spontaneist ideology" rooted in "the empiricist conception of knowledge," it is also "in the tailwinds of revisionism." 53 This is at once a far more serious charge to make against a self-identified Maoist filmmaker and one that seems counter-intuitive: much of Coup pour coup, after all, centers on the opposition between the revolutionary impetus of the textile workers and the class-collaborationist approach of the Party-aligned trade union leaders and would thus seem to constitute a political critique of the PCF. Cahiers argues, however, that the film's "anarcho-syndicalist" economism (excessively focusing on demands

no. 238-239 (May-June 1972), pp. 71-74; and Bertolt Brecht, "Notes sur l'opéra Grandeur et décadence de la ville de Mahagonny," Cahiers du cinéma no. 238-239 (May-June 1972), pp. 28-32.

51 Groupe Lou Sin, "Le 'Groupe Dziga Vertov' (2)," p. 5.

52 Guy Hennebelle and Gérard Lebanc, "Polémique à propos de Coup pour coup de Marin Karmitz," Écran 72 no. 4 (April 1972), pp. 41-44, here pp. 41, 43.

53 Groupe Lou Sin, "Deux films: Coup pour coup, Tout va bien," p. 9. 
for higher wages to the exclusion of other political issues) in fact represents a strain of revisionism that, dormant under the electoralist strategy initiated by Maurice Thorez, has recently resurfaced due to the resurgence of class struggle in France after 1968.

This political defect is accompanied by an "ultra-democratic" naïveté in the filmmaking process (its goal of "giving a voice to the workers") and a blind faith in the virtues of naturalist "authenticity" in the depiction of proletarian characters. The idea, for instance, that professional actors were capable of playing bosses and union leaders but not working-class characters was judged to be a "workerist" fantasy that was contemptuous of both the workers and the actors. By contrast, it is precisely because Yves Montand could perfectly well incarnate a worker that Godard/Gorin refused to give the actor such a role. More broadly, their work entailed not reducing or effacing the "contradictions between the economy of the film and the politics of its authors" but rather "exasperating them to make them productive," and it is this that allows the film to denote the contradictory position of bourgeois intellectuals in the class struggle and to carry out a "correct analysis" of revisionism, which is, at bottom, the "penetration of bourgeois ideology in the working-class." Moreover, in opposition to Karmitz's naturalism, which has the goal of a "restitution' of lived experience," Godard-Gorin's depiction of a factory strike is a "crystallization" or "condensed reflection" of the state of political struggle in France, and it is therefore able to confront the question of revisionism and class conflict in a way that Coup pour coup avoids. Whereas in Coup pour coup, "the accent is placed on affectivity," Tout va bien centers on questions of "process and logic." Hence, while the two films share a common referent (factory sequestrations in contemporary France), there is nonetheless for Cahiers "an antagonism as far as the formal line adopted in each film is concerned. ${ }^{54}$ Although the journal had made a marked political shift since the "Cinéma/idéologie/critique" editorial, its emphasis on formal criteria as the decisive factor in judging a film's ideological status remained, at least in mid-1972, intact.

In spite of a valuable formal analysis of both films, which rightly promoted Tout va bien as the more revolutionary work, Cahiers' lengthy comparison is marred by the excessive vigor with which Coup pour coup is attacked. If its conservative approach to performance, narrative, mise en scène and other formal questions is justifiably critiqued, the inference that the film shares in the political "revisionism" of the PCF is much more difficult to sustain, and the logic of Cahiers' argument in attempting to defend this stance becomes 
patently convoluted. Indeed, in November 1973, while still under the sway of its "Front culturel" period and thus more open to the instrumentalist notion of political art espoused by Karmitz, the journal retracted its claims about his film. Responding to a letter from Hennebelle-who maintained his strident opposition to Cahiers' earlier "intellectualist, aesthetic ultraleftism" but applauded its recent evolution-Bonitzer broadly defends the journal's positions but says of the Groupe Lou Sin article that "it was false and sectarian to write that Coup pour coup was a film 'in the tailwinds of revisionism' - in the tailwinds of reality, yes, but the reality which it reflected was not revisionist, since it was a question of a revolt against the bosses and the revisionists." The critic goes on to admit that Cahiers' response to the film should have considered its origins as a critique of Camarades and a reflection on The Salt of the Earth (which is itself, in Bonitzer's view, "a profound film that we ought to analyze").55

\section{The "Therrorized": Cahiers du cinéma and the later Godard}

This rectification notwithstanding, Godard's work retained its primacy for the journal..$^{5}$ As with his shift to Maoism at the turn of the decade, Godard's turn away from revolutionary politics preceded and was an influence on Cahiers' own political evolution over the course of the 1970s. As Bonitzer would later observe, Godard's films were a "barometer of the atmosphere of the time, ${ }^{\prime 57}$ and the Cahiers writers could not help but be swayed by his change in views. As early as Godard/Gorin's late 1972 trip to North America to tour Tout va bien and Letter to Jane on the college circuit, their Marxism-Leninism had already been adulterated by a reading of Deleuze/ Guatarri's Anti-OEdipe. ${ }^{8}$ By the time Godard completed his next film, Iciet

55 Pascal Bonitzer and Guy Hennebelle, "Pratique artistique et lutte idéologique," Cahiers du cinéma no. 248 (c. late 1973), pp. 53-64, here p. 64.

$5^{6}$ Although it was recanted, the journal's opposition to Karmitz perhaps reflected a reliable intuition: Coup pour coup was the last film Karmitz directed, and he would later go on to become one of the wealthiest moguls in the French film industry, founding the MK2 cinema chain, before acting as an advisor to the Sarkozy government in the 2000 .

57 Pascal Bonitzer, "Juste une image," Cahiers du cinéma no. 323-324 (April-May 1981), pp. 15-19, here p. 19 .

$5^{8}$ Interviews recorded at this time attest to this blend, with Godard/Gorin referring to capitalism as a "schizophrenic machine" and discussing the role of "flows of desire" in the cinema. See Jean-Luc Godard, interviewed by Ken Mate, Russell Campbell, Louis Alvarez and Maureen Turim, “Let's see where we are: Interview with Jean-Luc Godard and Jean-Pierre Gorin," Velvet Light Trap no. 9 (Summer 1973), pp. 30-36, here p. 33 . 
ailleurs in 1975 (a re-working of the footage shot in Palestine for Jusqu'à la victoire), Anne-Marie Miéville had replaced Gorin as his main collaborator, and he was now interrogating many of the basic tenets of politically engaged cinema that had governed his earlier work - a preoccupation that was shared by Cahiers in the mid-1970s. Godard's trilogy of "post-militant" films, made in the Sonimage studios in Grenoble (with Numéro deux and Comment ça va? following on from Ici et ailleurs), affected the Cahiers critics deeply. Serge Daney recalls vomiting from the emotional impact of a private screening of Ici et ailleurs in Godard's workshop, ${ }^{59}$ and the films incited a flurry of articles in the journal, with newcomers such as Thérèse Giraud, Alain Bergala, Serge Le Péron and Louis Skorecki joining more experienced members of the team in discussing Godard's work. ${ }^{60}$

In parallel with the "ultraviolet" work of Straub-Huillet, Godard's Sonimage films were held up by Bonitzer as occupying an "infrared" position in the spectrum of modern cinema. Whereas Straub "turns back the current of the cinema" by using theater, music and opera as source material, Godard pushes film towards its "infra-cultural avatars" (militant filmmaking, television, video). ${ }^{61}$ Both directors start out with the same principle: "all the cinema is a lie." At the same time, and paradoxically, both are united (and divided) by their "respect for the real." Bonitzer immediately recognizes the potentially counter-intuitive nature of this claim: after all, he concedes, "did we not kill ourselves, at Cahiers, in spreading the word that the 'respect for the real' was the worst form of idealism?" He clarifies, however, that "everything depends on what is understood by 'respect' and 'real"” and asserts: "First of all, the real is not there to be seen. This is what Godard and Straub teach us, working in the opposite direction to that of the mass media." ${ }^{62}$ Rather the real is what is hidden, it is the hors-champ, that which is covered by the black screens of Numéro deux and Ici et ailleurs (described as a "black hole from which the despotic voice of the director can be heard"). Central to the work of Godard and Straub/Huillet is a practice that does not conceive of representation as

59 Daney, L'Exercice a été profitable, Monsieur, p. 252. In the same text he also reveals that "Ici et ailleurs must be the film that I have shown the most often (from New York to Damascus, from Oporto to Brussels)." Ibid., p. 303.

6o See Serge Le Péron, "Numéro Deux: entre le zéro et l'infini, Cahiers du cinéma no. 262-263 (January 1976), pp. 11-13; Serge Toubiana, "Le hasard arbitraire," Cahiers du cinéma no. 262-263 (January 1976), pp. 15-19; Thérèse Giraud, "Retour du même," Cahiers du cinéma no. 262-263 (January 1976), pp. 20-24; and Louis Skorecki, “Questions/Réponses," Cahiers du cinéma no. 262-263 (January 1976), pp. 28-29.

61 Bonitzer, "J.-M.S. et J.-L.G.," p. 5.

62 Ibid.pp. 6-7. 
a "system" or a "metaphysics" but as "nourishment offered to the eye for the real, a representation which, in all senses of the word, cooks [cuisine] the real, sacrifices it by producing it for the eye." ${ }^{\prime 3}$ On the basis of this discussion, Bonitzer sets Godard's technique of déchaînement (unlinking) against the détournement of the situationists: the latter is a "second-degree regime" and, in the end, is nothing but an advertising technique, which only serves to confirm the receivers (the intellectual classes) in the self-estimation of their own intelligence. By contrast, Godard and the Straubs "sovereignly despise all second-degree regimes, all metalanguage," and this is the root cause of the vociferous contempt that their films so often provoke. ${ }^{64}$

Daney's response to Numéro deux and Ici et ailleurs also drew on an implicit alliance between Godard and Straub/Huillet: two issues after the "Straubian pedagogy" of his article on Moses und Aron ("Un tombeau pour l'œil"), he returned with a "Godardian pedagogy." The title of this text, "Le thérrorisé" (the therrorized) plays on the homophony between the words "theorize" and "terrorize" in French, and the article itself centers on Daney's idiosyncratic concept of the discours du manche. ${ }^{65}$ In spite of all the differences between Godard's Sonimage work and the GDV-era films, Daney sees a striking element shared by them: the role of pedagogy. The discours $d u$ manche is an authoritative register of speech whose assertions cannot be argued with, and all of Godard's post-1968 films are dominated by the "positive content" that it conveys. While this content may vary (MarxistLeninist politics in Pravda and Vent d'est, Althusserian theory in Luttes en Italie, Brecht and the role of intellectuals in revolutionary struggle in Tout va bien, radical feminism in Numéro deux), the discours du manche remains unchanged: "it always comes from above and is quick to lay blame." ${ }^{66}$ It is also invariably borne by the voice of a woman, who often speaks in a declamatory or even hectoring tone ("the voice which reprimands, resumes, advises, teaches, explains, theorizes and even $t(h)$ errorizes is always a

63 Ibid., pp. 8-9.

64 Ibid., pp. 9-10.

65 Serge Daney, "Le thérrorisé (pédagogie godardienne)," Cahiers du cinéma no. 262-263 (January 1976), pp. 32-40. Translated as “The T(h)errorized (Godardian Pedagogy)," trans. Bill Krohn and Charles Cameron Ball, https://www.diagonalthoughts.com/?p=1620 (accessed January 1, 2021). In a footnote to their translation, Krohn/Ball note that the term discours du manche (literally, the "discourse of the handle") is "better left untranslated, and explain it by writing, "Implicit in this Daneyism is the idea of 'being on the right side' (the handle by which the tool must be grasped), and, of course, the image of the phallus. It also glances at Lacan's term for the language of the obsessional neurotic: le Discours du Maître the Discourse of the Master)."

66 Ibid., p. 35 . 
woman's voice"). Such a technique is labeled a "strange feminism," since "it is not clear that feminist demands are satisfied with this 'place' the men no longer want, with this 'power' which they've let drop." 67

The uniqueness of Godard's cinema is, however, his undecidable relationship with this "good" discourse: he seems to be speaking from a position of conviction in this discourse's message at the same time as critiquing it, subverting it, or simply mocking it. With the semi-parodic nature of their voice-over commentaries, the GDV films already attested to this undecidabality, but the film that works most with this contradiction is Ici et ailleurs. For Daney: “It is clear that the film's self-interrogation (the kind of disjunction it effects in every direction: between here and elsewhere, images and sounds, 1970 and 1975) is possible and intelligible only because, early on, the syntagma 'Palestinian revolution' already functions as an axiom." ${ }^{68}$ The key scene of Ici et ailleurs, and one that affected Daney deeply, comes late in the film, when PLO fighters are shown discussing strategy on a riverbank. Godard relates that the translators on the shoot had not rendered their conversation accurately, transmitting their words as blithe revolutionary homilies, when in fact the fedayeen were complaining to their commander about being sent to their certain death on a suicide mission. A few months after the filming, Black September took place, and all the individuals on screen perished at the hands of Jordanian troops. It was several years later that Godard had the idea of freshly translating the resistance fighters' actual words, only to find out that he was watching dead men speak about their own impending demise, a fact he had not originally perceived because, as a formula repeated throughout the film puts it, "the sound was too loud" — that is, the forced optimism of the revolutionary discourse had drowned out any ability to comprehend the reality of the political situation. For Daney, then, the chief task involved in making Ici et ailleurs amounts "quite simply, to translating the soundtrack, making sure one can hear what is said, or better, that one listens to it."69

Ici et ailleurs' interrogation of political engagement in the context of the image-sound relationship made it one of the most important films of the decade for Cahiers, and the journal's editors frequently invoked the maxim that "the sound is too loud" when discussing militant cinema. A more direct collaboration between the journal and the filmmaker arose on the occasion of Cahiers' $300^{\text {th }}$ issue in May 1979, editorial control of which was given to Godard. The filmmaker used the opportunity to deliver a dense work of 
text/image collage incorporating fragments of an interview given to Cahiers and a 50-page dossier on his aborted project to make a television series in the newly independent country of Mozambique. In a letter to Daney and Toubiana that appears at the beginning of the special issue, Godard writes that "what it is possible to do does not correspond to the real conditions in which a film journal is bought and read, and we must take this into account." He describes what follows as "a few random documents from my drawers which could have been part of the events that we would have chosen to review [passer en revue], on the condition that we would prefer to see things clearly rather than know about them deeply."70

In retrospect, the collages appearing in this special issue strikingly anticipate the montage practices later developed by Godard in Histoire $(s)$ du cinéma and other works of the 1980 s to 200os. Indeed, issue no. 300 of Cahiers was published at roughly the same time that Godard was honing his discourse on the history of the cinema in a lecture series in Montreal. ${ }^{71}$ Several Cahiers alumni not only defended this work, they were also closely involved in its creation. Daney, for instance, was interviewed at length for episode $2 \mathrm{~A}$ of Histoire(s), and his ideas on the transformation of visual culture in the late twentieth century exhibit strong parallels with the views expressed by Godard, whose central claim in Histoire $(s)$ is that the cinema effectively "died" after World War II due to its inability to represent the Nazi concentration camps..$^{2}$ Aumont, meanwhile, who was able to view provisional versions of Histoire $(s)$ before it was completed, was the first figure to dedicate a monograph to the work, Amnésies in $1999 .{ }^{73}$ More broadly, the influence that Godard's œuvre has had on the Cahiers writers over the last fifty years is so diffuse that it pervades a wide range of their theoretical, aesthetic and political concerns, and it continues up to the present day. In 2011, for instance, Narboni published a rhapsodic tribute to Godard's Film socialisme in Trafic. Here, the former Cahiers critic notes that the film's title-which unmistakably evokes Godard's Marxist period — is disconcertingly equivocal, since Godard

70 Cahiers du cinéma no. 300 (May 1979, special issue), p. 3.

71 See Jean-Luc Godard, Introduction à une véritable histoire du cinéma, ed. Joël Farges (Paris: Éditions Albatros, 1980).

72 Extracts from the dialogue between Daney and Godard were also printed in Libération and, later, in Cahiers. See Serge Daney and Jean-Luc Godard, "Histoire(s) du cinéma: Godard fait des histoires," Libération, December 26, 1988. Repr. in Jean-Luc Godard, Godard par Godard vol. II: 1984-1998, ed. Alain Bergala (Paris: Cahiers du cinéma, 1998), pp. 161-174; and Serge Daney and Jean-Luc Godard, "Dialogue entre Jean-Luc Godard et Serge Daney," Cahiers du cinéma no. $5^{13}$ (May 1997), pp. 49-55.

73 Jacques Aumont, Amnésies (Paris: P.O.L., 1999). 
chooses to translate socialism as "generosity' or 'hope' or even 'openness"' and refrains from any more precise definition of the term. ${ }^{74}$ But Narboni also points out that the voyage charted by the film around the Mediterranean recalls landmarks of 1960 s cinema that were vigorously defended by Cahiers: not only Godard's own Le Mépris but also Sollers/Pollet's Méditérranée, whose fragmentary, symphonic approach to montage anticipated much of Godard's own practice in Film socialisme. Resonances, therefore, of Godardian "political modernism" from the 1960s and 1970s can still be felt in the cinema-and, it is worth adding, the film criticism —of the 2010s.

\section{Works Cited}

Jacques Aumont, "L'étang moderne (Week-End)," Cahiers du cinéma no. 199 (March 1968), pp. 59-6o.

—, "Berlin 69," Cahiers du cinéma no. 215 (September 1969), pp. 41-46.

—, "Comment on écrit l'histoire," Cahiers du cinéma no. 238-239 (May-June 1972), pp. 64-70.

—, Amnésies (Paris: POL, 1999).

Pierre Baudry, "La critique et Tout va bien," Cahiers du cinéma no. 240 (JulyAugust 1972), pp. 10-18.

Pascal Bonitzer, “Réalité' de la dénotation," Cahiers du cinéma, no. 229 (May 1971), pp. 39-41. Translated as "Reality' of Denotation," trans. Lindley Hanlon, in Nick Browne (ed.), Cahiers du Cinéma vol. III:1969-1972 The Politics of Representation (London: BFI, 1990), pp. 248-253.

—, "Juste une image," Cahiers du cinéma no. 323-324 (April-May 1981), pp. 15-19.

—, interviewed by Stéphane Bouquet, Emmanuel Burdeau and François Ramone, "Nos années non-légendaires: Entretien avec Pascal Bonitzer," in Emmanuel Burdeau (ed.), Cinéma 68 (Paris: Cahiers du cinéma, 2008 [1998]).

Jacques Bontemps, "Une libre variation imaginative de certains faits (La Chinoise)," Cahiers du cinéma no. 194 (October 1967), pp. 30-34.

Bertolt Brecht, "Notes sur l'opéra Grandeur et décadence de la ville de Mahagonny," Cahiers du cinéma no. 238-239 (May-June 1972), pp. 28-32.

Jean-Louis Comolli, “À rebours? (Alphaville)," Cahiers du cinéma no. 168 (July 1965), pp. 86-87.

—, "Le point sur l'image (La Chinoise)," Cahiers du cinéma no. 194 (October 1967), pp. 29-30.

—, "Le cahier des lecteurs," Cahiers du cinéma no. 215 (September 1969), pp. 4-9. 
Serge Daney, "Le thérrorisé (pédagogie godardienne)," Cahiers du cinéma no. 262263 (January 1976), pp. 32-40. Translated as "The T(h)errorized (Godardian Pedagogy)," trans. Bill Krohn and Charles Cameron Ball, https://www.diagonalthoughts.com/?p=1620 (accessed January 1, 2021)..

—, La Rampe (Paris: Cahiers du cinéma, 1983).

—, L'Exercice a été profitable, Monsieur (Paris: P.O.L., 1993).

—, Persévérance (Paris: P.O.L., 1993). Translated as Postcards from the Cinema, trans. Paul Douglas Grant (Oxford: Berg, 2007).

— and Jean-Luc Godard, "Histoire(s) du cinéma: Godard fait des histoires," Libération, December 26, 1988. Repr. in idem., Godard par Godardvol. II: 1984-1998, ed. Alain Bergala (Paris: Cahiers du Cinéma, 1998), pp. 161-174.

—, "Dialogue entre Jean-Luc Godard et Serge Daney," Cahiers du cinéma no. 513 (May 1997), pp. 49-55.

Daniel Fairfax, "The Dialectics of Montage in Jean-Luc Godard (1965-1998)," MPhil thesis, University of Sydney, 2010.

Thérèse Giraud, "Retour du même," Cahiers du cinéma no. 262-263 (January 1976), pp. 20-24.

Jean-Luc Godard, "Frère Jacques," Cahiers du cinéma no. 106 (April 1960), p. 4. Translated as "Frère Jacques," in idem., Godard on Godard, trans. and ed. Tom Milne (New York: Da Capo Press, 1972), pp. 163-164.

—, interviewed by Jean Collet, Michel Delahaye, Jean-André Fieschi, André S. Labarthe and Bertrand Tavernier, "Jean-Luc Godard," Cahiers du cinéma no. 138 (December 1962), pp. 21-39. Translated as "Interview with Jean-Luc Godard," in idem., Godard on Godard, trans. and ed. Tom Milne (New York: Da Capo Press, 1972), pp. 171-196.

—, "Pierrot mon ami," Cahiers du cinéma no. 171 (October 1965), pp.17-18. Translated as "Pierrot My Friend," in idem., Godard on Godard, trans. and ed. Tom Milne (New York: Da Capo Press, 1972), pp. 213-215.

—, interviewed by Jean-Louis Comolli, Michel Delahaye, Jean-André Fieschi and Gérard Guégan, "Parlons de Pierrot: nouvel entretien avec Jean-Luc Godard," Cahiers du cinéma no. 171 (October 1965), pp. 18-34. Translated as "Let's Talk about Pierrot," in idem., Godard on Godard, trans. and ed. Tom Milne (New York: Da Capo Press, 1972), pp. 215-234.

—, interviewed by Jacques Bontemps, Jean-Louis Comolli, Michel Delahaye, Jean Narboni, "Lutter sur deux fronts: conversation avec Jean-Luc Godard," Cahiers du cinéma no. 194 (October 1967), pp. 12-26, 66-70. Translated as "Struggle on Two Fronts: A Conversation with Jean-Luc Godard," trans. D.C.D., Film Quarterly, vol. 22 no. 2 (Winter 1968-1969), pp. 20-35.

—, interviewed by J.-P.C. and G.L., "Un cinéaste comme les autres," Cinéthique no. 1 (c. January 1969), pp. 8-12. 
—, interviewed by Alain Jouffroy, "Entretien," Le Fait public no. 2 (January 1969), repr. in Jean Collet (ed.), Jean-Luc Godard, $4^{\text {th }}$ ed. (Paris: Éditions Seghers, 1974), pp. 145-157.

—, "Premiers ‘sons anglais," Cinéthique no. 5 (September-October 1969), p. 14.

_ , "Warum ich hier spreche...," translated into German by Gerhard Theuring, Filmkritik vol. 19 no. 9 (September 1975), pp. 420-429.

—, Introduction à une véritable histoire du cinéma, ed. Joël Farges (Paris: Éditions Albatros, 1980).

—, interviewed by Noël Simsolo, À voix nues, France Culture, November 21, 1989.

— and Jean-Pierre Gorin, interviewed by Marcel Martin, "Le Groupe 'Dziga Vertov,"” Cinéma 70 no. 151 (December 1970), repr. in Jean-Luc Godrd, Godard par Godard vol. I: 1950-1984, ed. Alain Bergala (Paris: Cahiers du Cinéma, 1998),, pp. 342-350.

— and Jean-Pierre Gorin, interviewed by Marlène Belilos, Michel Boujut, JeanClaude Deschamps and Pierre-Henri Zoller, "Pourquoi Tout va bien?: Entretien avec Jean-Luc Godard and Jean-Pierre Gorin," Politique-Hebdo no. 26, April 27 1972. Repr. in Jean-Luc Godrd, Godard par Godard vol. I: 1950-1984, ed. Alain Bergala (Paris: Cahiers du Cinéma, 1998), pp. 367-375.

Groupe Dziga Vertov, “Bande paroles de Luttes en Italie," Cahiers du cinéma no. 238239 (May-June 1972), pp. 40-57.

__, "Bande paroles de Pravda," Cahiers du cinéma no. 240 (July-August 1972), pp. 19-30.

—, "Bande paroles de Vent d'est," Cahiers du cinéma no. 240 (July-August 1972), pp. 31-50.

Groupe Lou Sin d'intervention idéologique, "Deux Films: Coup pour coup et Tout va bien," Cahiers du cinéma no. 238-239 (May-June 1972), pp. 5-24.

—, "Le 'Groupe Dziga-Vertov': Sur les films du 'groupe,'” Cahiers du cinéma no. 238239 (May-June 1972), pp. 34-39, and Cahiers du cinéma no. 240 (July-August 1972), pp. 4-9.

Guy Hennebelle and Gérard Lebanc, "Polémique à propos de Coup pour coup de Marin Karmitz," Écran 72 no. 4 (April 1972), pp. 41-44.

Serge Le Péron, “Numéro Deux: entre le zéro et l'infini, Cahiers du cinéma no. 262-263 (January 1976), pp. 11-13.

George Lellis, Bertolt Brecht, Cahiers du Cinéma and Contemporary Film Theory (Ann Arbor: UMI Research Press, 1982).

Julia Lesage, "Visual Distancing in Godard," Wide Angle vol. 1 no. 3 (March 1976), pp. 4-13.

Jean Narboni, "Notes sur 2 ou 3 choses que je sais d'elle," Cahiers du cinéma no. 186 (January 1967), pp. 32-33. Translated as "Notes on Two or Three Things...," Cahiers du Cinéma in English no. 10 (May 1967), p. 31.

— (ed.), Godard par Godard (Paris: Pierre Belfond, 1968). 
—, "Brecht et le cinéma," Cahiers du cinéma no. 225 (November-December 1970), p. 56 .

—, "Film socialisme de Jean-Luc Godard, Trafic no. 8o (Winter 2011), pp. 53-61.

—, "Dans le texte (One Plus One)," Cahiers du cinéma no. 213 (June 1969), pp. 59-6o.

La Rédaction, "Réponses à Politique Hebdo," Cahiers du cinéma no. 229 (MayJune 1971), pp. 61-64.

François Regnault, "Les Camisards et le film d'histoire," Cahiers du cinéma no. 238239 (May-June 1972), pp. 71-74.

Louis Skorecki, “Questions/Réponses," Cahiers du cinéma no. 262-263 (January 1976), pp. 28-29.

Kristin Thompson, "Sawing through the Bough: Tout va bien as a Brechtian film," Wide Angle vol. 1 no. 3 (March 1976), pp. 38-51.

Serge Toubiana, "Le hasard arbitraire," Cahiers du cinéma no. 262-263 (January 1976), pp. 15-19. 
